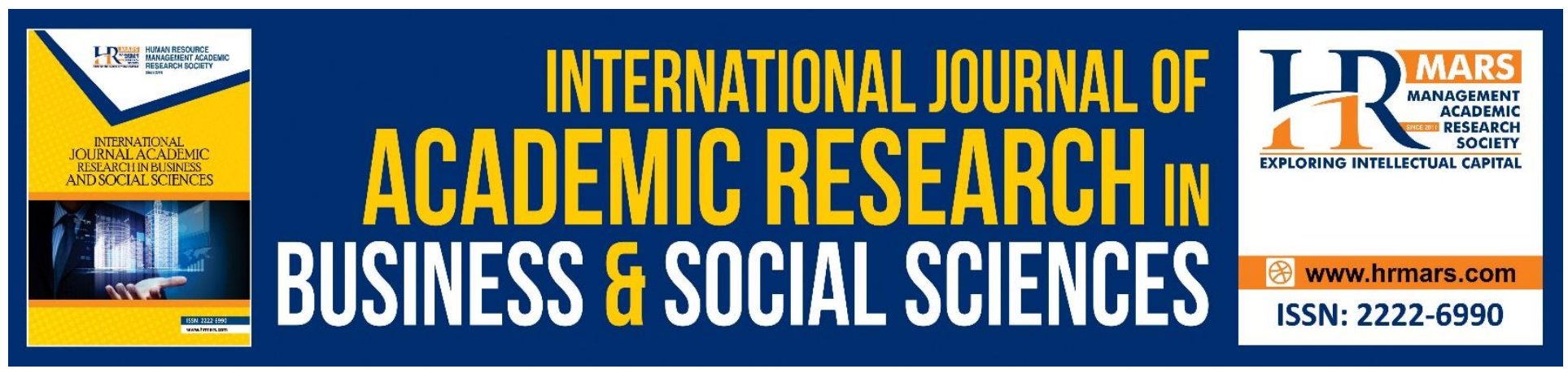

\title{
The Impact E-Commerce Service Quality to Loyalty Evidence Study in Malaysian Hotel Industry
}

Mutia Sobihah Binti Abd Halim, Ghaith Abdulraheem Ali Alsheikh

To Link this Article: http://dx.doi.org/10.6007/IJARBSS/v8-i12/5071

DOI: $10.6007 /$ IJARBSS/v8-i12/5071

Received: 14 Oct 2018, Revised: 23 Dec 2018, Accepted: 25 Dec 2018

Published Online: 29 Dec 2018

In-Text Citation: (Halim \& Alsheikh, 2018)

To Cite this Article: Halim, M. S. B. A., \& Alsheikh, G. A. A. (2018). The Impact E-Commerce Service Quality to Loyalty Evidence Study in Malaysian Hotel Industry. International Journal of Academic Research in Business and Social Sciences, 8(12), 766-776.

\section{Copyright: (C) 2018 The Author(s)}

Published by Human Resource Management Academic Research Society (www.hrmars.com)

This article is published under the Creative Commons Attribution (CC BY 4.0) license. Anyone may reproduce, distribute, translate and create derivative works of this article (for both commercial and non-commercial purposes), subject to full attribution to the original publication and authors. The full terms of this license may be seen

at: http://creativecommons.org/licences/by/4.0/legalcode

Vol. 8, No. 12, 2018, Pg. 766 - 776

http://hrmars.com/index.php/pages/detail/IJARBSS

JOURNAL HOMEPAGE

Full Terms \& Conditions of access and use can be found at http://hrmars.com/index.php/pages/detail/publication-ethics 


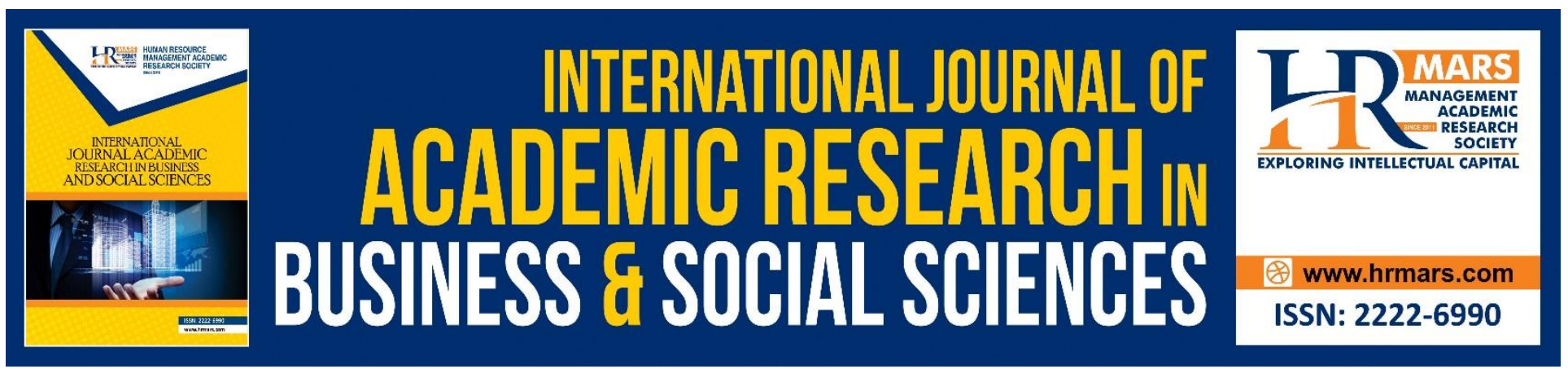

\title{
The Impact E-Commerce Service Quality to Loyalty Evidence Study in Malaysian Hotel Industry
}

\author{
Mutia Sobihah Binti Abd Halim \\ Universiti Sultan Zainal Abidin (UniSZA) / Faculty of Economics \& Management Sciences \\ Email: mutiasobihah@unisza.edu.my \\ Ghaith Abdulraheem Ali Alsheikh \\ Universiti Sultan Zainal Abidin (UniSZA) / Faculty of Economics \& Management Sciences \\ Email: aligaith89@yahoo.com
}

\begin{abstract}
The tourism industry is viewed as the top service industry in terms of size, particularly its hotel sector branch. The management of customer loyalty through the quality of E-commerce service in the longrun is imperative in attracting considerable number of foreign tourists into Malaysia. Service quality refers to the way the level of service delivery meets the expectations of customers. Hence, in realm of E-commerce, the quality of service is measured by gauging the way the website satisfies the customers' expectations. This paper provided a discussion of E-commerce service quality and tourism loyalty relationship in the Malaysian East coast hotel industry. The paper aimed to provide insight into E-commerce service quality among the foreign tourists patronizing the hotels. This study is using a questionnaire as the survey instrument in a quantitative type of research. The sample comprised of 100 tourists staying in above 3-star hotels in Malaysian East Coast. Based on the findings of this preliminary study, E-commerce service quality was found to be affected by perceived product, perceived user interface quality, perceived security risk and perceived privacy. This indicates that in the hotel industry, successful provision of E-commerce service quality will garner an influx of patrons. The entire identified factors were included in the actual survey with the aim of improving the quality of E-commerce services in the hotel industry of Malaysia. Lastly, the study enhances such quality by generating E-customer loyalty.
\end{abstract}

Keywords: E-commerce service quality, customer loyalty, Malaysian East Coast hotel industry.

\section{INTRODUCTION}

The spread of E-commerce has brought about heightened market competition among businesses as the interaction between e-commerce and customers are increased towards delivering higher value. According to Yang (2001) and Zeithaml (2002), experienced business that use E-commerce has 
acknowledged that the presence of websites and low price is not just the major drivers of successful commerce, but this also includes service quality of E-commerce. Meanwhile, Santos (2003) referred to E-commerce service quality as assessing and judging the delivery of E-service from the viewpoint of customers in the virtual market realm. Notably, a business will fail in delivering the right service quality level to its customers sans the adoption of quality management approach ensuring system quality.

Added to the above, E-customer loyalty is expensive and difficult to establish as explained by van Riel et al. (2001) and for its achievement, quality service is called for that satisfies customers. Similar to any industry, the factor in obtaining competitive advantage over rivals is through customer loyalty. In this regard, Parasuraman et al. (1991) revealed that via service experiences, customers really care about relationships and in E-business, execution of customer retention methods can lead to developing customer relationship and in turn, business development through increased loyalty of customers (Heskett et al., 1994).

Despite several empirical researches in literature like that by Zeithaml et al. (2005) and Park and Kim (2003) exploring the variable of E-commerce service quality, in the Malaysian hotel industry context, it is still largely unexplored. In fact, the present study, to the researcher's best knowledge, is the first study to address the variable dimensions in the Malaysian East Coast case. It is noteworthy that owing to the lack of studies in this area, a study framework for the industry is still lacking, and thus, the present work develops a framework to match the E-commerce service in Malaysian hotel industry.

\section{Problem Statement}

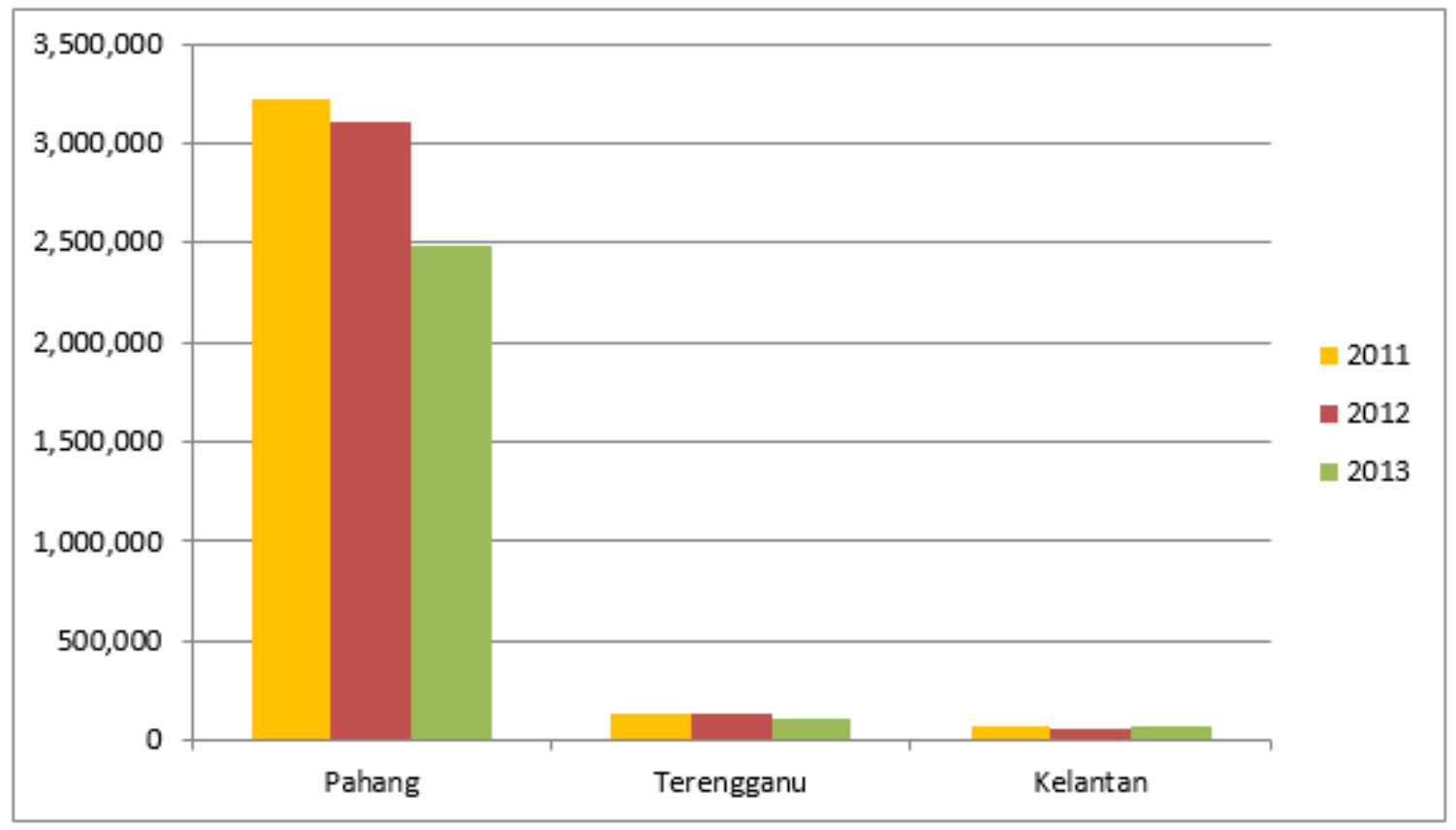

Figure 1: Number of Foreign Tourists Stay Hotel East Coast Malaysia (Tourism Malaysia, 2015) 
The rate of foreign tourists patronizing three-star hotels in the Malaysian East coast (see Figure 1) follows a declining trend from year to year, with the exception of 2013. For instance, in Pahang hotel the number of foreign tourists declined from 3,218,135 tourists (2011) to 3,107,088 and 2,481,302 tourists for 2012 and 2013 respectively. Similarly, in Terengganu, the number of foreign tourists declined from 132,520 (2011) to 132,406 tourists (2012) and further down to 109,942 tourists the following year (2013). In Kelantan hotel, the number of tourists fluctuates from 69,331 tourists (2011) to 60,588 (2012) and finally, 72,942 (2013).

In general, the decreasing trend in hotel occupancy rates may be attributed many factors, with the inclusion of the service weaknesses, ineffective promotional processes, and lack of management of Internet facilitated services, in the form of hotel websites and booking online (Raihan et al., 2011). On the whole, the tourists' numbers appear to fluctuate and the government is attempting to resolve this issue to maintain high numbers of tourists.

The presence of challenges and competitiveness in the tourism and hospitality industry calls for indepth study of customer satisfaction and loyalty for the country to achieve a reputation as the preferred destination in Asia. As for the global scenario, customer loyalty is significantly related to heightened profits and development of organizations in the long-term (Mustafa, 2011; Reichheld, 1995). The service industry, particularly, both communication and information are acknowledged as critical factors and thus, efficient web technology has contributed value to the delivery of service. Prior empirical studies (e.g., Mustafa, 2011) indicated that $35-40 \%$ constituting the sales revenue gathered from the E-commerce websites were brought on by repeat patrons. In addition, achieving customer loyalty through E-commerce online is more challenging compared to traditional business environment as websites can be accessed easily but cannot be trusted the same way. Hence, it is crucial to determine the factors influencing customer loyalty when it comes to E-commerce use among hotels.

On the basis of a report around 120 million adults in the U.S. used the Internet in 2005 alone (Travel Industry Association of America, TIA), (constituting 56\% of the total 216.1 million adults). From the Internet users, around 84\% (101.3 million) used the Internet to search information concerning their travels (TIA, 2008). This shows that foreign tourists are likely to use E-commerce to explore and decide on their travel plans and this provides an opportunity for tourism representatives in Malaysia to attract foreign tourists.

\section{Literature Review}

In literature, studies dedicated to E-commerce service quality can be traced back to the early years of 1984. Cronin and Taylor (1992) explained that service quality is difficult to define and measure owing to its abstract nature and this can also be the reason behind the lack of service quality models.

In the present study, literature was reviewed concerning E-commerce service quality, particularly from the works of 16 researchers. Their contexts are similar to the Malaysian hotel industry and the dimensions of E-commerce service quality used were mainly adopted from Mustafa's (2011) study, a 
INTERNATIONAL JOURNAL OF ACADEMIC RESEARCH IN BUSINESS AND SOCIAL SCIENCES

Vol. 8, No. 12, Dec, 2018, E-ISSN: 2222-6990 @ 2018 HRMARS

current study using dimensions that are suitable for the study context. The 16 studies reviewed are summarized in Table 1.

Table 1: Summary of studies concerning E-commerce service quality review

\begin{tabular}{|c|c|c|}
\hline Authors (year) & Model & Dimensions \\
\hline Gronroos (1984) & $\mathrm{CPQ}$ & $\begin{array}{l}\text { Measures consumer's expectation of service } \\
\text { compared with the customer's perception of } \\
\text { the service actually received }\end{array}$ \\
\hline \multirow[t]{5}{*}{ Parasuraman et al. (1985) } & SERVQUAL & 1. Reliability \\
\hline & & 2. Responsiveness \\
\hline & & 3. Assurance \\
\hline & & 4. Empathy \\
\hline & & 5. Tangibles \\
\hline \multirow[t]{2}{*}{ Davis (1989) } & TAM & 1. Perceived usefulness \\
\hline & & 2. Perceived ease of use \\
\hline \multirow[t]{6}{*}{ Delone and McLean (1992) } & IS success & 1. System quality \\
\hline & & 2. Information quality \\
\hline & & 3. Use \\
\hline & & 4. User satisfaction \\
\hline & & 5. Individual impact \\
\hline & & 6. Organizational impact \\
\hline \multirow[t]{4}{*}{ Liu and Arnett (2000) } & & 1. Quality of Information \\
\hline & & 2. Service \\
\hline & & 3. Security \\
\hline & & 4. Playfulness perceived by consumers \\
\hline
\end{tabular}


INTERNATIONAL JOURNAL OF ACADEMIC RESEARCH IN BUSINESS AND SOCIAL SCIENCES Vol. 8, No. 12, Dec, 2018, E-ISSN: 2222-6990 @ 2018 HRMARS

Yoo and Donthu (2001)

Barnes and Vidgen (2002)

Loiacono (2002)
SITEQUAL

Web site quality

scale

WebQual (TM)
1. Esthetic competitive value

2. Ease of use

3. Design

4. Ease of ordering

5. Corporate and brand equity

6. Processing speed

7. Security

8. Product uniqueness

9. Product quality assurance

1. Usability of web site

2. Information quality

3. Interaction between customer and web

Site

1. Information fit-to-task

2. Interactivity

3. Trust

4. Visual appeal

5. Innovativeness

6. Flow/emotional appeal

7. Design appeal

8. Intuitiveness

9. Response time

10. Integrated communications

11. Business process

12. Viable substitute 
INTERNATIONAL JOURNAL OF ACADEMIC RESEARCH IN BUSINESS AND SOCIAL SCIENCES

Vol. 8, No. 12, Dec, 2018, E-ISSN: 2222-6990 C 2018 HRMARS

Schubert and Dettling (2002)

WolfinbargereTailQ and Gilly (2003)

Park and Kim (2003)

Yang et al. (2004)

Lee and $\operatorname{Lin}(2005)$

Zeithamlet al. (2005)

Ho \& Lee (2007)

Mustafa I. Eid (2011)

\begin{tabular}{|c|c|}
\hline & 1. Ease of use \\
\hline & 2. Usefulness and trust \\
\hline & 3. Use of the extend web assessment method \\
\hline & as a tool \\
\hline eTailQ & 1. Web site design \\
\hline & 2. Reliability \\
\hline & 3. Privacy/security \\
\hline & 4. Customer service \\
\hline & 1. Information quality \\
\hline & 2. User interface quality \\
\hline & 3. Security perception \\
\hline & 1. Usability \\
\hline & 2. Usefulness \\
\hline & 3. Adequacy of information \\
\hline & 4. Accessibility \\
\hline & 5. Interaction \\
\hline Revised & 1. Web site deign \\
\hline SERVQUAL & 2. Reliability \\
\hline & 3. Responsiveness \\
\hline & 4. Trust \\
\hline & 5. Personalization \\
\hline E-S-QUAL & 1. Routine service encounters \\
\hline & 2. An auxiliary scale for service errors \\
\hline Evaluation & 1. Information quality \\
\hline of travel service & 2. Security \\
\hline website quality & 3. Ease of use \\
\hline & 4. Availability \\
\hline & 5. Customization \\
\hline & 6. Community \\
\hline & 7. Responsiveness \\
\hline & 8. Delivery fulfillment. \\
\hline E-commerce & 1. Perceived user interface quality \\
\hline service quality & 2. Perceived information quality \\
\hline & 3. Perceived privacy \\
\hline & 4. Perceived security risk \\
\hline
\end{tabular}

1. Ease of use

2. Usefulness and trust

. Use of the extend web assessment method

1. Web site design

Reliability

. Privacy/security

4. Customer service

1. Information quality

. User interface quality

3. Security perception

1. Usability

. Usefulness

3. Adequacy of information

4. Accessibility

1. Web site deign

2. Reliability

3. Responsiveness

4. Trust

5. Personalization

2. An auxiliary scale for service errors

1. Information quality

2. Security

3. Ease of use

4. Availability

5. Customization

6. Community

Responsiveness

2. Perceived information quality

4. Perceived security risk

\section{Methodology}

This study adopted a quantitative approach, using questionnaire survey as the study instrument. The sample comprised of 100 tourists staying in above 3-star hotels in Malaysian East Coast. The hotel industry was selected as it is an increasingly growing industry in Malaysia. In this regard, studies concerning Malaysian hotel industry are still lacking, particularly those examine Ecommerce service quality and its facilitation of the loyalty of E-customers. Eighteen items (18) were used to measure E-commerce service quality gauged through a scale that ranged from 1 (strongly disagree) to 5 (strongly agree). The dimensions include perceived product, perceived user interface quality, perceived security risk and perceived privacy. 
INTERNATIONAL JOURNAL OF ACADEMIC RESEARCH IN BUSINESS AND SOCIAL SCIENCES

Vol. 8, No. 12, Dec, 2018, E-ISSN: 2222-6990 C 2018 HRMARS

After gathering the required data, data analysis was carried out with the use of SPSS, v 20, with the first test carried out being normality. The skewness of measure was used - with skewness of 0.0 , data is considered to be perfectly distributed. Data is considered to be normally distributed with measures ranging from -0.1 to 1.0 (Zainuddin, 2010). Following the normality test, the reliability test was run using the Cronbach's alpha. According to Nunnally (1978), 0.6 is the least value of Cronbach's alpha that reflects factor measurement.

\section{Findings and Discussions}

The preliminary study obtained $100 \%$ rate of response. The results for each factor in the preliminary study are presented in Table 2 . The skewness of perceived user interface was found to be -0.19 , and that of perceived product was -0.40 , perceived security risk was 0.01 , and lastly, perceived privacy was -0.22 . With regards to the skewness value, perceived product obtained a value of -0.40 , perceived risk of 0.01 and perceived privacy of -0.22 . As mentioned, skewness value between -0.1 to 0.1 is considered to be normal and thus, the normality test conducted revealed normal distribution, providing a go ahead for further analysis.

Table 2: Summary of the normality test results

\begin{tabular}{lccccccc}
\hline \multicolumn{1}{c}{ Element } & No. of & Minimum & Maximum & Mean & Std. & $\begin{array}{c}\text { Std. } \\
\text { Skewness }\end{array}$ \\
& Sample & Score & Score & & Error & Deviation & \\
\hline $\begin{array}{l}\text { Perceived user interface } \\
\text { quality }\end{array}$ & 100 & 4.7510 .0 & 7.3950 & 0.11850 & 1.18502 & -0.191 & \\
Perceived product & 100 & 5.00 & 9.80 & 7.5420 & 0.11896 & 1.18962 & -0.400 \\
Perceived security risk & 100 & 5.00 & 10.0 & 7.4275 & 0.12233 & 1.22335 & 0.010 \\
Perceived privacy & 100 & 4.80 & 10.0 & 7.4880 & 0.11534 & 1.15341 & -0.222 \\
& & & & & & & \\
\hline
\end{tabular}

Table 3 tabulates the Cronbach alpha values of the variable perceived user interface comprising of four items is 0.89 , that of perceived product comprising of five items is 0.86 , and that of perceived security risk comprising of four items is 0.89 . Lastly, the Cronbach's alpha value found for perceived privacy comprising of five items is 0.88 (see Table 3). Nominally (1978) mentioned that the least Cronbach's alpha value is 0.60 and as such, the entire factors in the preliminary study provided reliability of internal consistency measure exceeding 0.60 (the cut-off value). 
INTERNATIONAL JOURNAL OF ACADEMIC RESEARCH IN BUSINESS AND SOCIAL SCIENCES Vol. 8, No. 12, Dec, 2018, E-ISSN: 2222-6990 @ 2018 HRMARS

Table 3: Summary of the reliability statistics results

\begin{tabular}{lcc}
\hline \multicolumn{1}{c}{ Element } & $\begin{array}{c}\text { Number of items in an } \\
\text { element }\end{array}$ & $\begin{array}{c}\text { Cronbach's } \\
\text { Alpha }\end{array}$ \\
\hline $\begin{array}{l}\text { Perceived user interface } \\
\text { quality }\end{array}$ & 4 & 0.89 \\
Perceived product & 5 & 0.86 \\
Perceived security risk & 4 & 0.89 \\
Perceived privacy & 5 & 0.88 \\
\end{tabular}

The findings show that foreign tourists staying in above 3-star hotels in Malaysian East Coast confirmed significant dimensions (perceived user interface quality, perceived security risk perceived product, and perceived privacy) of E-commerce service quality. This finding can be utilized in further studies to obtain more accurate findings.

\section{Conclusion}

In this paper, the researcher confirmed that the dimensions of E-commerce service quality leads to E-customer loyalty. These dimensions were examined in Malaysian hotel industry and were obtained from 16 studies in literature. The study sample comprised of 100 foreign tourists randomly chosen from above 3-star hotels and resorts in the Malaysian East Coast.

Analysis in the form of normality and reliability tests obtained from the survey indicated acceptable E-commerce service quality dimensions to the Malaysian hotel industry, namely perceived user interface quality, perceived product, perceived security risk and perceived privacy. They are invaluable in developing E-customer loyalty. Studies of this caliber are still few and far between in the context of Malaysia. This study is thus expected to contribute to the development of hotel industry in the country and on the whole, its tourism sector. Hotel management can use the findings to enhance E-commerce service quality to establish and maintain E-customer loyalty in Asian hotels, particularly in Malaysia.

\section{References}

Barnes, S. and Vidgen, R. (2002), "An integrative approach to the assessment of e-commerce quality", Journal of Electronic Commerce Research, Vol. 3 No. 3, pp. 114-27.

Cronin, J.J. and Taylor, S.A. (1992), "Measuring service quality: a re-examination and extension", Journal of Marketing, Vol. 56 No. 3, pp. 55-68.

Davis, F.D. (1989), "Perceived usefulness, perceived ease of use, and user acceptance of information technology", MIS Quarterly, Vol. 13 No. 3, pp. 319-39. 
INTERNATIONAL JOURNAL OF ACADEMIC RESEARCH IN BUSINESS AND SOCIAL SCIENCES Vol. 8, No. 12, Dec, 2018, E-ISSN: 2222-6990 C 2018 HRMARS

Delone, W. and McLean, E. (1992), "Information systems success: the quest for the dependent variable", Information Systems Research, Vol. 3 No. 1, pp. 60-95.

Gronroos, C.A. (1984), "Service model and its marketing implications", European Journal of Marketing, Vol. 4, pp. 36-44.

Heskett, J.L., Jones, T.O., Loveman, G.W., Saiser, W.E. and Schlesinger, L.A. (1994), "Putting the service profit chain to work", Harvard Business Review, March-April, pp. 164-74.

Ho, C., \& Lee, Y. (2007). The development of an e-travel service quality scale. Tourism Management, 28, 1434-1449.

Lee, G.-G. and Lin, H.-F. (2005), "Customer perceptions of e-service quality in online shopping", International Journal of Retail \& Distribution Management, Vol. 33 Nos 2/3, pp. 161-76.

Liu, C. and Arnett, K.P. (2000), "Exploring the factors associated with web site success in the context of electronic commerce", Information and Management, Vol. 38 No. 1, pp. 23-33.

Loiacono, E., Watson, R. and Goodhue, D. (2002), "WebQual(tm): a web site quality instrument", paper presented at American Marketing Association: Winter Marketing Educators Conference, Austin, TX.

Nunally, J. C. (1978). Psychometric Theory. New York: McGraw-Hill.

Parasuraman, A., Berry, L.L. and Zeithaml, V.A. (1991), "Understanding customer expectations of service", Sloan Management Review, Vol. 32 No. 3, pp. 39-48.

Parasuraman, A., Zeithaml, V. and Berry, L. (1985), "A conceptual model of service quality and its implications for future research", Journal of Marketing, Vol. 49 No. 4, pp. 41-50.

Park, C.-H. and Kim, Y.-G. (2003), "Identifying key factors affecting consumer purchase behavior in an online shopping context", International Journal of Retail \& Distribution Management, Vol. 31 No. 1, pp. 16-29.

Schubert, P. and Dettling, W. (2002), "Extended web assessment method (EWAM) - evaluation of ecommerce applications from the customer's viewpoint", Proceedings of the 35th HICSS, IEEE Computer Society, Washington, DC.

Santos, J. (2003), "E-service quality: a model of virtual service quality dimensions", Management Service Quality, Vol. 13 No. 3, pp. 233-46. 
INTERNATIONAL JOURNAL OF ACADEMIC RESEARCH IN BUSINESS AND SOCIAL SCIENCES

Vol. 8, No. 12, Dec, 2018, E-ISSN: 2222-6990 C 2018 HRMARS

van Riel, A.C.R., Liljander, V. and Jurriens, P. (2001), “Exploring customer evaluations of e-service: a portal site", International Journal of Service Industry Management, Vol. 12 No. 4, pp. 359-77. Wolfinbarger, M. and Gilly, M. (2003), "eTailQ: dimensionalizing, measuring and predicting etail quality", Journal of Retailing, Vol. 79, pp. 183-98.

Yang, Z. and Fang, X. (2004), "Online service quality dimensions and their relationships with satisfaction", International Journal of Service Industry Management, Vol. 15 No. 3, pp. 302-26.

Yang, Z. (2001), "Customer perceptions of service quality in internet-based electronic commerce", Proceedings of the 30th EMAC Conference, Bergen, pp. 8-11.

Yoo, B. and Donthu, N. (2001), "Developing a scale to measure the perceived service quality of internet shopping sites (sitequal)", Quarterly Journal of Electronic Commerce, Vol. 2 No. 1, pp. 31-47.

Zainudin, A. (2010). Research Methodology for Business \& Social Science (2nd ed.). UPENA.

Zeithaml, V.A. (2002), "Service excellent in electronic channels", Managing Service Quality, Vol. 12 No. 3, pp. 135-8.

Zeithaml, V.A., Parasuraman, A. and Malhotra, A. (2005), "E-S-QUAL: a multi-item scale for assessing electronic service quality", Journal of Service, Vol. 7 No. 3, pp. 213-33. 